\title{
The genus Alcyonium (Octocorallia: Alcyonacea: Alcyoniidae) in Chile
}

\author{
L.P. VAN OFWEGEN ${ }^{1}$, V. HÄUSSERMANN ${ }^{2} \&$ G. FÖRSTERRA ${ }^{2}$ \\ ${ }^{1}$ Nationaal Natuurhistorisch Museum, P.O. Box 9517, 2300 RA Leiden, The Netherlands. E-mail: ofwegen@naturalis.nnm.nl \\ ${ }^{2}$ Universidad Austral de Chile, Departamento de Biología Marina, Campus Isla Teja, Casilla 567, Valdivia, Chile, and Fundación \\ Huinay, Chile.E-mail:vreni_haeussermann@yahoo.de; gunter_forsterra@yahoo.com
}

\begin{abstract}
Four new species of Alcyonium (Octocorallia: Alcyoniidae) are described from Chile. They occur in the shallow waters of the southern fjord region. One of them is an encrusting species, the other three form digitate colonies. Encrusting forms of A. grandis Casas et al., 1997, and A. haddoni Wright \& Studer, 1889 were also found in the fjord region, bringing the number of Alcyonium species recorded for Chile to eight. For all six recently collected species SEM images of sclerites are presented, and a key to the Chilean Alcyonium species is included.
\end{abstract}

Key words: Coelenterata, Cnidaria, Octocorallia, Alcyonacea, Alcyoniidae, benthos, Alcyonium, A. grandis Casas et al., 1997; A. haddoni Wright \& Studer, 1889, new species, Chile

\section{Introduction}

The shallow water soft coral fauna of the Chilean coast is still almost completely unknown. To date three Alcyonium species have been described from Chile. First, A. antarcticum Wright \& Studer, 1889; specimens described by May (1899) as Alcyonium paessleri from Smyth Channel, Chile, synonymized with A. antarcticum by Verseveldt \& Ofwegen (1992). Second, A. haddoni Wright \& Studer, 1889, found $315 \mathrm{~m}$ deep in the Messier Channel. Third, A. sollasi, Wright \& Studer, 1889, found $100 \mathrm{~m}$ deep in the Straits of Magellan.

Beginning in 1997, Verena Häussermann and Günter Försterra have investigated the anthozoan fauna of Chile with a focus on the South Chilean fjord region and collected many specimens. This soft coral collection includes several clavulariids, one of which has been described recently, viz. Incrustatus comauensis Ofwegen et al., 2006, a species of Renilla, and six species of Alcyonium, which are described in this paper.

\section{Material and methods}

The material is deposited in the Museo de Zoología de la Universidad de Concepción, Chile (MZUC-UCCC); National Museum of Natural History, formerly Rijksmuseum van Natuurlijke Historie, Leiden, The Netherlands (RMNH); and the Zoologische Staatssammlung München, Germany (ZSM). In the material collection data, VH stands for V. Häussermann, GF for G. Försterra, LA for Liz Atwood (all Fundación Huinay), and PW for Philippe Willenz (Royal Belgian Institute of Natural Sciences, Bruxelles). Samples of A. glaciophilum n. sp. (RMNH Coel. 34935), A. haddoni (ZSM 20061191), A. roseum n. sp. (ZSM 20061195), and A. yepayek n. sp. (MZUC-UCCC 32684) have been sent to Dr. Catherine S. McFadden (Harvey Mudd College, Claremont, USA) for molecular study. A. roseum proved to be distinct genetically from the other species, but no DNA difference could be found between A. glaciophilum, A. yepayek and A. haddoni in either the msh1 or ITS gene 
regions. Pending more material for study, we decided to describe the new species A. glaciophilum and A. yepayek, based on different sclerites and colony form.

\section{Key to the Chilean Alcyonium species}

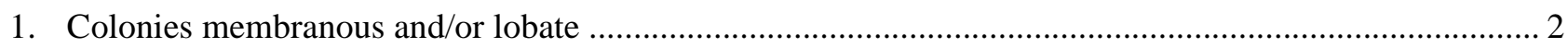

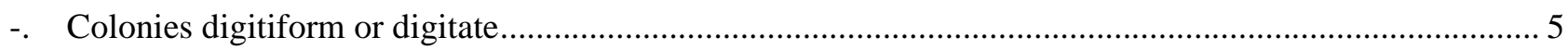

2. Interior base with sparsely ornamented rods .......................................... sollasi Wright \& Studer, 1889

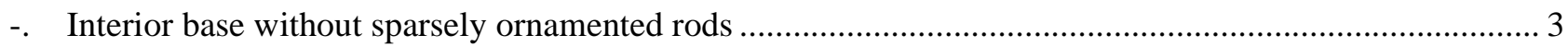

3. Only capstans and spindles in coenenchyme …............................................ grandis Casas et al., 1997

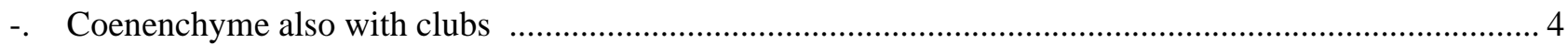

4. Capstans very tuberculate, tentacle bases with clubs ....................................................... roseum $\mathrm{n}$. $\mathrm{sp}$

-. Capstans sparsely tuberculate, tentacle bases without clubs .......... A. antarcticum Wright \& Studer, 1889

5. Interior with spindles only .............................................................. haddoni Wright \& Studer, 1889

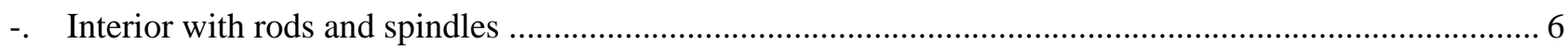

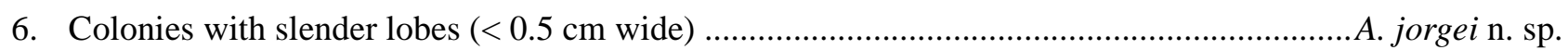

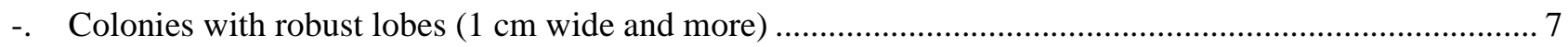

7. Interior of complete colony with sparsely ornamented rods, most clubs without central wart ..................

-. Only interior of base with sparsely ornamented rods, most clubs with central wart......... A. yepayek n. sp.

\section{Class Anthozoa Ehrenberg, 1831}

Subclass Octocorallia Haeckel, 1866

Order Alcyonacea Lamouroux, 1812

Family Alcyoniidae Lamouroux, 1812

Genus Alcyonium Linnaeus, 1758

Alcyonium glaciophilum n. sp.

(Figs. 1a, 2a, 3a, 4)

Holotype and three microscope slides: RMNH Coel. 34935, Chile, Tempano Fjord, $16 \mathrm{~km}$ from head, south shore, 4842'50.0" S, 74¹1'02.7" W, depth 10-15 m, coll. VH \& GF, 25 March 2005.

Paratypes: MZUC-UCCC 32677, one colony, same data as holotype; ZSM 20061186, two colonies, same data as holotype.

Description. Holotype $3.5 \mathrm{~cm}$ high and $3 \mathrm{~cm}$ wide, consisting of 4 slightly flattened lobes (Fig. 1a).

Polyps distributed over the whole surface of the colony, almost reaching the base. The polyps, which are completely withdrawn, are up to $0.70 \mathrm{~mm}$ wide and $0.45 \mathrm{~mm}$ in length; calyces are not present.

Anthocodiae have a collaret composed of 3 to 5 rows of spindles (Fig. 3a); these spindles are up to 0.50 mm long, with simple tubercles (Fig. 4a-b). Points have spindles similar to those of the collaret, with clubs present distally, up to $0.30 \mathrm{~mm}$ long (Fig. 4c). In the tentacles spiny rods are found, up to $0.20 \mathrm{~mm}$ long (Fig. $4 d)$.

The surface layer of the top of the colony has clubs, up to $0.30 \mathrm{~mm}$ long, with spiny heads (Fig. 4e); the interior has spindles, up to $0.50 \mathrm{~mm}$ long, with simple tubercles, (Fig. $4 \mathrm{f}-\mathrm{g}$ ). Furthermore, sparsely ornamented rods are also present in the interior (Fig. 4h). 


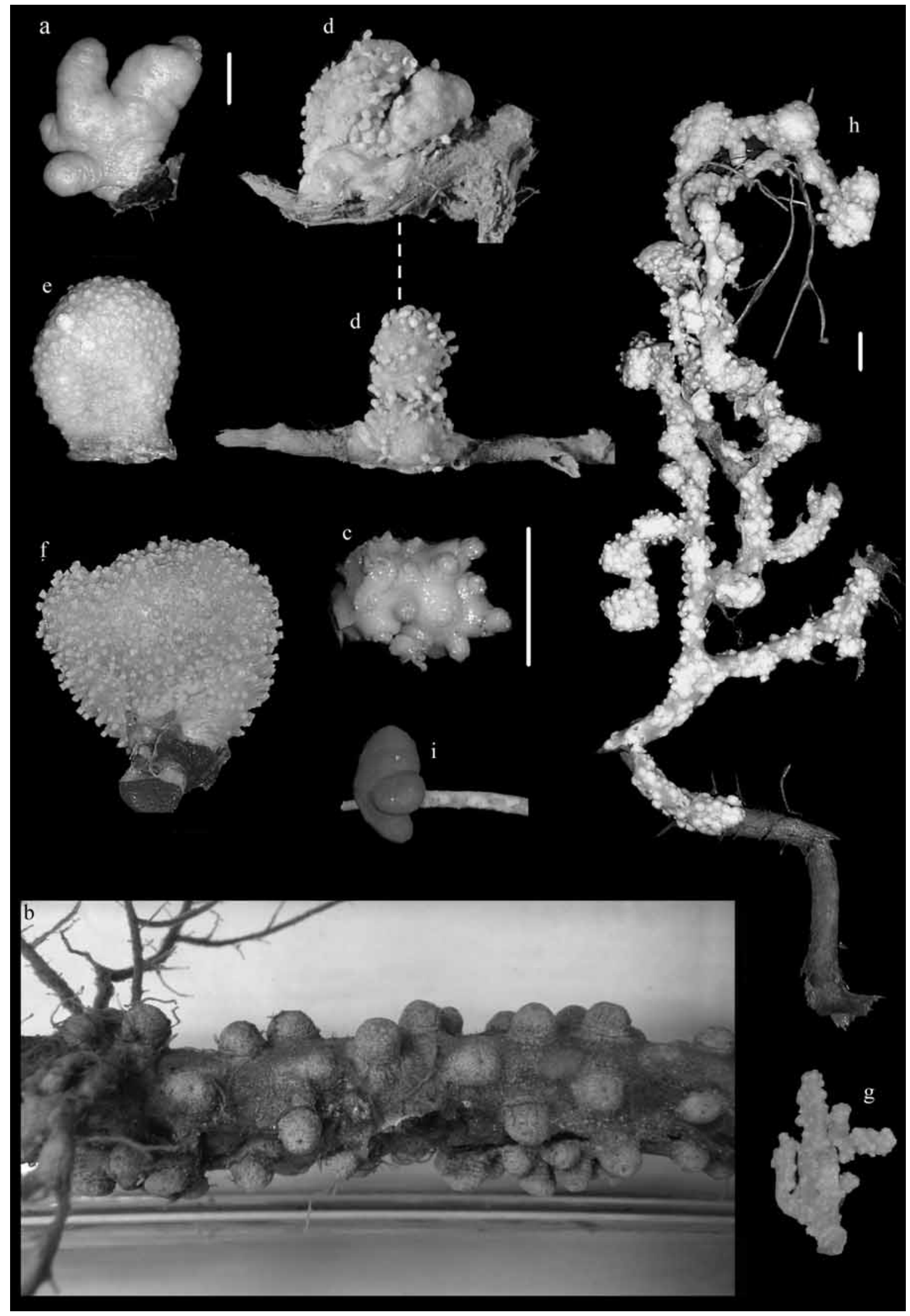

FIGURE 1. a, RMNH Coel. 34935, holotype Alcyonium glaciophilum n. sp.; b, A. grandis ZSM 20061187; c, A. grandis RMNH Coel. 34936; d, two syntypes of A. haddoni; e, A. haddoni RMNH Coel. 34937; f, A. haddoni RMNH Coel. 34938; g, RMNH Coel. 34942, holotype of A. jorgei; h, RMNH Coel. 34946, holotype of A. roseum; i, RMNH Coel. 34948 , holotype of $A$. yepayek. Scales $1 \mathrm{~cm}$, that at $\mathrm{c}$ only applies to $\mathrm{c}$, that at h only to $\mathrm{h}$. 

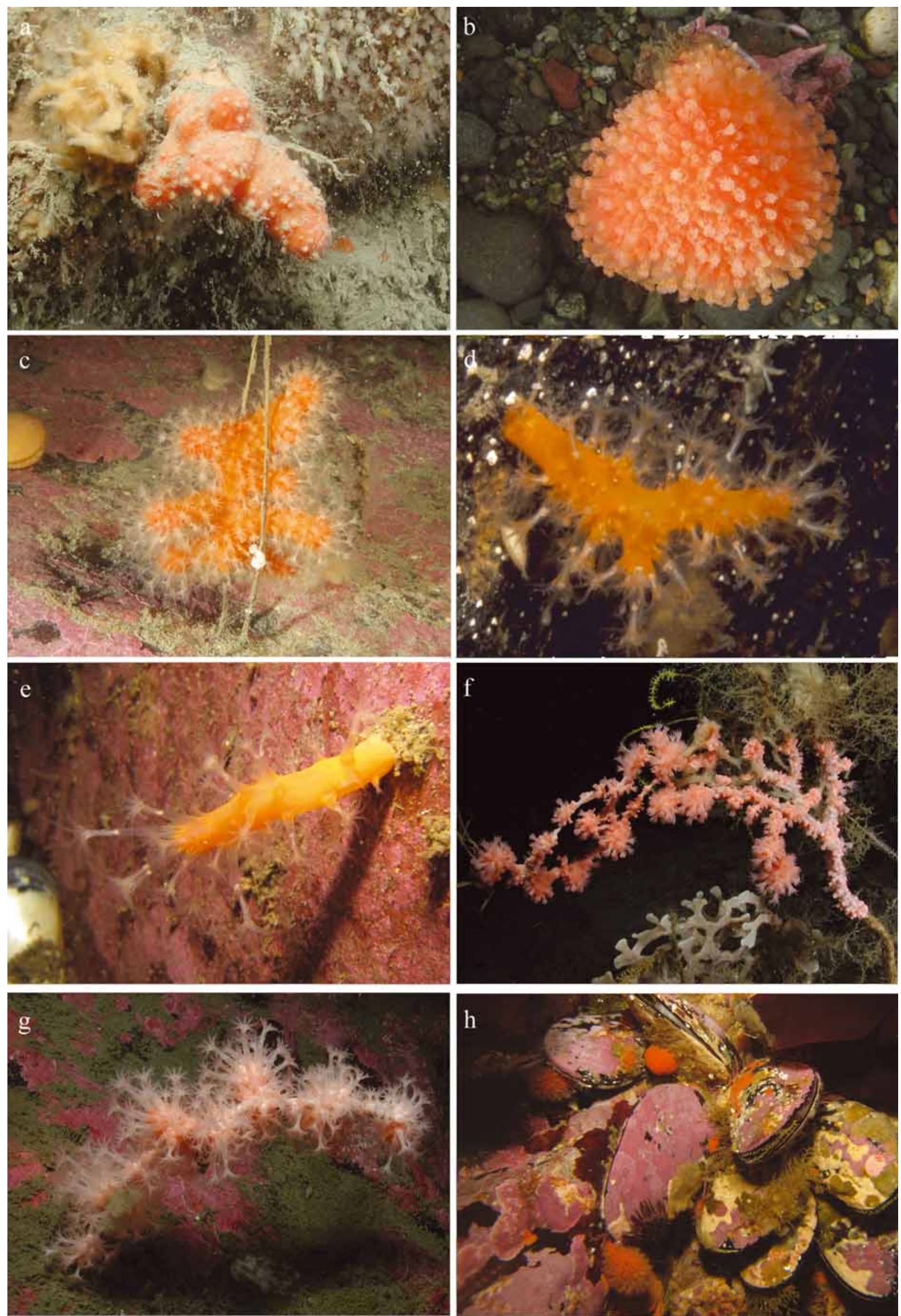

FIGURE 2. Live colonies; a, holotype Alcyonium glaciophilum; b-c, A. haddoni; d-e, A. jorgei; f, holotype A. roseum; $\mathrm{g}$, paratype A. roseum; h, A. yepayek. 

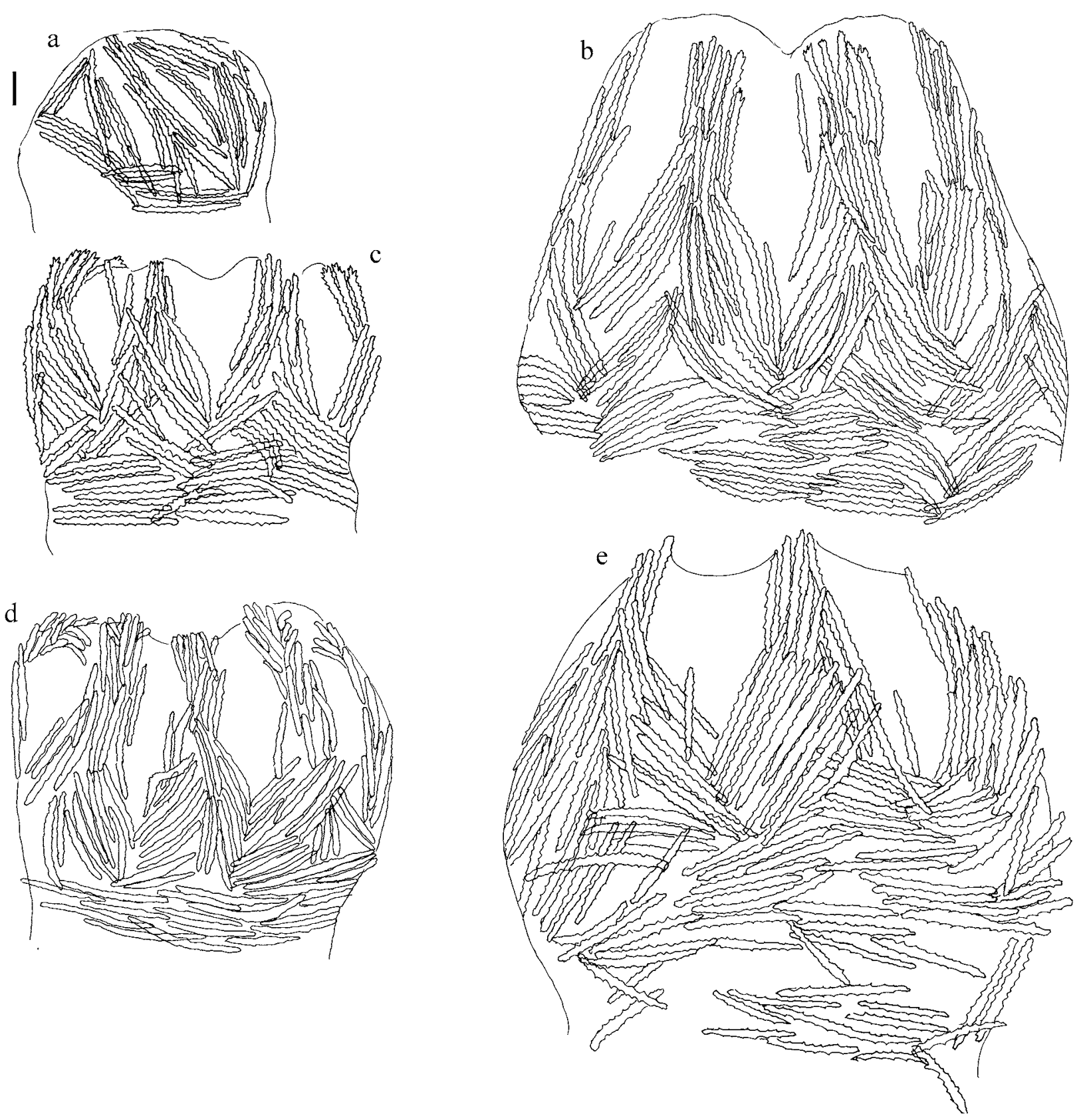

FIGURE 3. Lateral views of polyp armature; a, RMNH Coel. 34935, holotype Alcyonium glaciophilum; b, RMNH Coel. 34940, A. haddoni; c, RMNH Coel. 34938, A. haddoni; d, RMNH Coel. 34942, holotype A. jorgei; e, RMNH Coel. 34946, holotype A. roseum. Scale $0.10 \mathrm{~mm}$.

The base of the colony has sclerites similar to those of the top of the colony (Fig. 4i-k).

Colour. Alive or preserved the colonies are orange (Fig. 2a), anthocodial sclerites are colourless, other sclerites yellow.

Etymology. The species name is from the Latin glacies, ice, and philum, nature, since it only seems to appear in fjords influenced by icebergs (and their sediment).

Habitat, distribution and abundance. The species was found between 10 and $15 \mathrm{~m}$ depth on vertical rocky walls of the Tempano fjord (Central Patagonian Zone) which is under strong influence of glacial sediment. It is one of the few species that withstands strong stress from fine glacial sediment.

Variability. One ZSM 20061186 paratype is digitiform. 


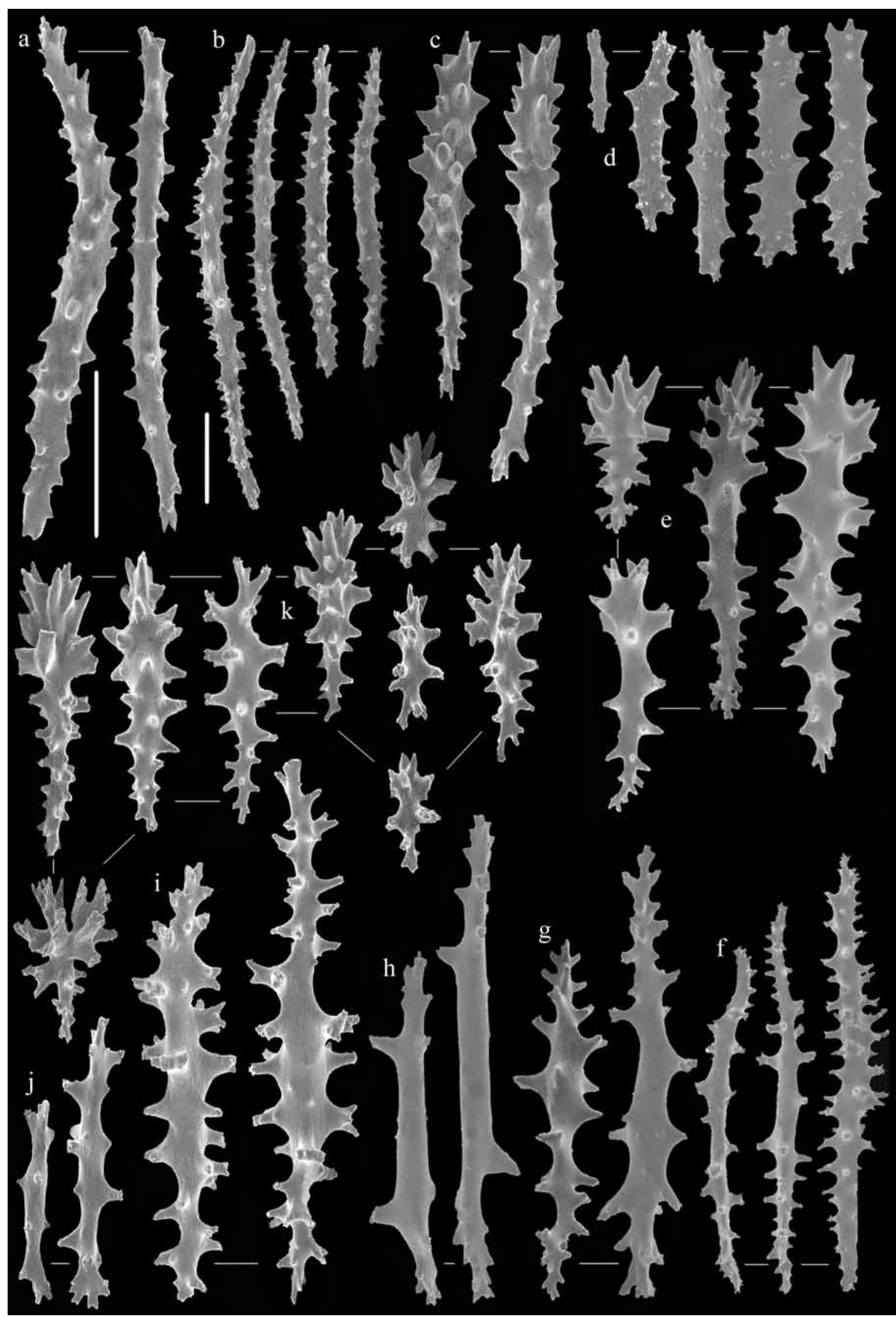

FIGURE 4. Alcyonium glaciophilum n. sp., holotype RMNH Coel. 34935; a-b, collaret spindles; c, point clubs; d, tentacular rods; e, clubs of surface layer of top of colony; $\mathrm{f}-\mathrm{g}$, spindles of interior of top of colony; h, rods of interior of top of colony; $i$, spindles of interior of base of colony; $j$, rods of interior of base of colony; $k$, clubs of surface layer of base of colony. Scales $0.10 \mathrm{~mm}$, that at $\mathrm{b}$ also applies to $\mathrm{f}$, that at a to all others. 
Remarks. Alcyonium sollasi Wright \& Studer, 1889, from the Straits of Magellan and Shag Rocks, has similar rods in the interior (see Verseveldt \& Ofwegen, 1992). It differs in colony shape, with many rounded lobes, and in having clubs with less spiny heads in the surface of the coenenchyme. Moreover, preserved colonies have a brown or yellowish white color, while all specimens of A. glaciophilum n. sp. are orange.

A. haddoni Wright \& Studer, 1989, from the Messier Channel, Chile, and A. patagonicum (May, 1899), from the Patagonian Shelf, can have a similar colony shape as A. glaciophilum n. sp. Both species, however, lack the sparsely ornamented rods in the interior of the colony.

A. yepayek n. sp. also has a similar colony shape as A. glaciophilum n. sp., and also has sparsely ornamented rods in interior of the base of the colony. It differs in lacking these rods in the interior of the top of the colony, and most clubs having a central wart.

\section{Alcyonium grandis Casas et al., 1997}

(Figs. 1b-c, 5, 11)

Alcyonium grandis Casas et al., 1997: 304, figs. 5-7.

Material: RMNH Coel. 34936, fragment of colony, Chile, Islas Diego Ramírez/Drake Passage (approx. 56³0' S; 68 $45^{\prime}$ W), depth 1800 m, coll. Claudio Vera, 2001; ZSM 20061187, fragment of colony, South Georgia, depth 1200 m, coll. Eugenio Olivares, September 2003.

Description of RMNH Coel. 34936. The colony is membranous, about $1.5 \mathrm{~cm}$ long and $1 \mathrm{~cm}$ wide (Fig. 1c).

Polyps are evenly distributed over the colony. Calyces are dome shaped and all polyps are partly retracted with tentacles withdrawn.

Anthocodiae have a collaret of a few irregularly arranged rows of spindles; the points have many spindles. In order to preserve as much as possible of the fragment no microscope slides were made for drawing the anthocodial sclerite arrangement. The collaret spindles are up to $0.55 \mathrm{~mm}$ long, with spines and prominent simple tubercles (Fig. 5a-b). Points have spindles similar to those of the collaret, with clubs present distally, up to $0.30 \mathrm{~mm}$ long (Fig. $5 \mathrm{c}$ ). The tentacles are without sclerites.

The surface layer of calyces and membrane has exclusively capstans, $0.10-0.15 \mathrm{~mm}$ long (Fig. $5 \mathrm{~d}$, h). The interior has tuberculated spindles (Fig. $5 \mathrm{f}-\mathrm{g}$, i), the longest present in the calyces, up to $0.40 \mathrm{~mm}$ long. Some of these spindles are club-like (Fig. 5e), but real clubs were not observed.

Colour. The preserved colony is white, and all sclerites are colourless.

Habitat, distribution and abundance. The species occurs in South Georgia, and was collected only once in Chile, at $1800 \mathrm{~m}$ depth.

Remarks. ZSM 20061187 is also only a fragment, but a large part of that colony has been photographed, showing more of its colony shape (Fig. 1b). The species was originally described from off Shag Rocks and South Georgia, at 152-335 m depth (Casas et al., 1997: 308). All six colonies of the type series showed colonies with numerous lobes, the largest colony, the holotype, even reaching $16.5 \mathrm{~cm}$ in height. It is remarkable that the present material forms encrusting sheets. However, comparison of sclerites showed the present material in close agreement with A. grandis, and therefore we identified it as this species despite the big difference in colony shape.

The species differs from all the other species in Chile by the total lack of clubs in the coenenchyme. 


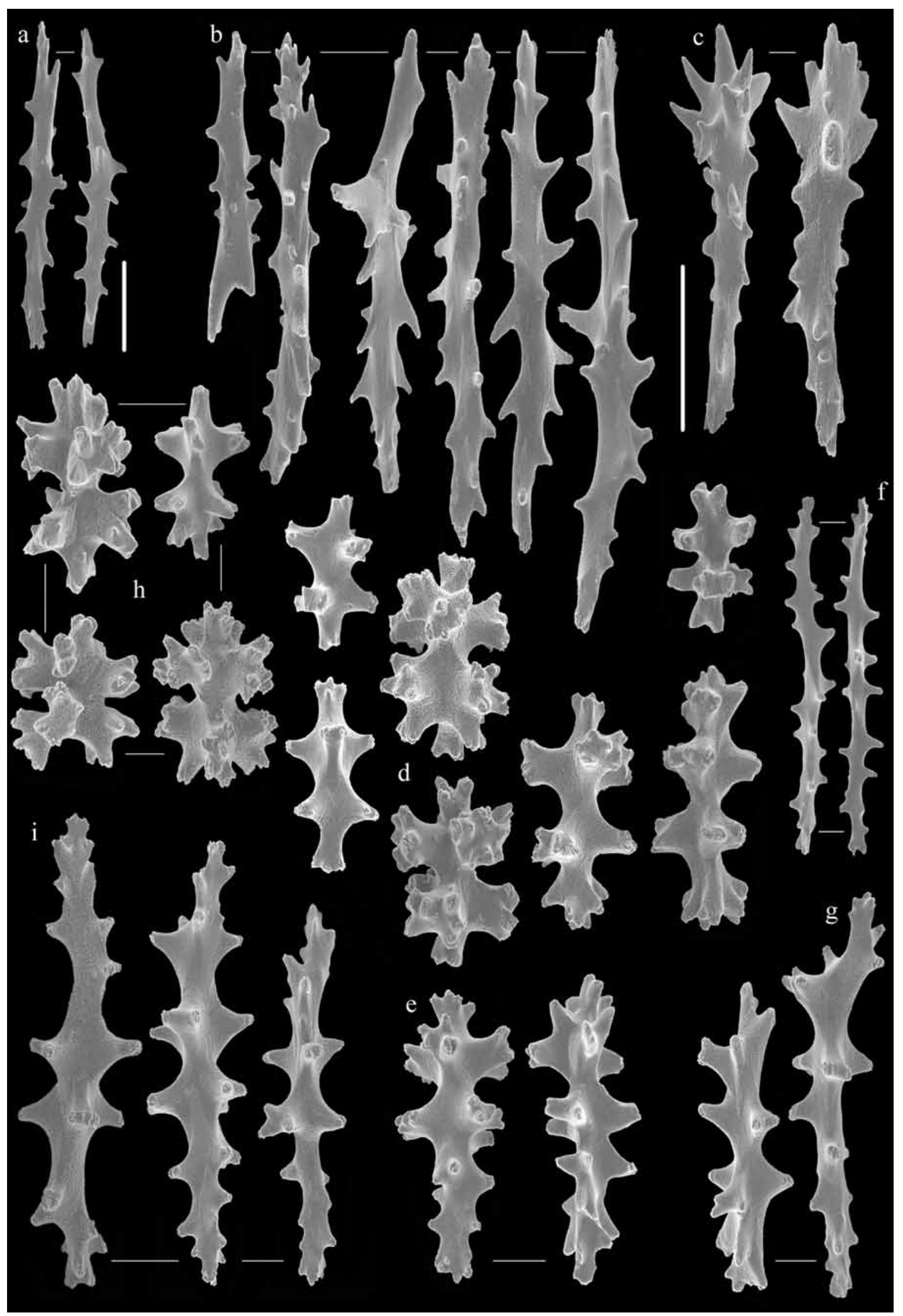

FIGURE 5. Alcyonium grandis Casas et al., RMNH Coel. 34936; a-b, collaret spindles, c, point clubs; d, capstans of calyces; e, club-like spindles of calyces; $f-g$, spindles of calyces; $h$, capstans of membrane, i, spindles of membrane. Scales $0.10 \mathrm{~mm}$, that at a also applies to $\mathrm{f}$, that at $\mathrm{c}$ to all others. 
Alcyonium haddoni Wright \& Studer, 1889: 240, pl. 42 fig. 6.

? Alcyonium haddoni Verseveldt, 1967: 5, figs 2, 6C-D.

Not Alcyonium haddoni Pérez \& Zamponi, 2004: 4, fig. 2B.

Material: RMNH Coel. 34937, two colonies and two microscope slides, Chile, Piedra Lile, Isla Laitec, 4310'58.6" S, 73³8'27.2" W, depth 13-20 m, coll. VH \& GF, 4 March 2005; RMNH Coel. 34938, one colony and three microscope slides, Chile, Cailín Island, 4309' $02.1^{\prime \prime} \mathrm{S}, 73^{\circ} 35^{\prime} 30.9^{\prime \prime} \mathrm{W}$, depth $10 \mathrm{~m}$, coll. VH \& GF, 31 January 2001; MZUC-UCCC 32678, one colony, Chile, Canal Ofhidro, 48º9'52.1" S, 74²3'48.4" W, steep wall, low diversity, few overhangs, depth 15 m, coll. VH, 16 March 2006; ZSM 20061188, one colony, Chile, Canal Pasaje, 50²7'49.2" S, 7507'41.6" W, depth $20 \mathrm{~m}$, slowly descending wall, many terraces, medium diversity, thick mussel beds, coll. VH \& GF, 9 March 2006; ZSM 20061189, four colonies, Chile, Canal Pitt Chico, 5050'07.1" S, 7408'20.9" W, very mixed, steep walls, strong current, lots of Alcyonium, hydrocorals and crabs, depth 6 m, coll. PW \& LA; MZUC-UCCC 32679, one colony, Chile, Seno Waldemar, $48^{\circ} 23^{\prime} 48.5^{\prime \prime} \mathrm{S}, 74^{\circ} 43^{\prime} 48.8^{\prime \prime} \mathrm{W}$, slope/wall, some terraces, patches of high diversity, depth $25 \mathrm{~m}$, coll. GF, 15.iii.2006; ZSM 20061190, three colonies, Chile, Canal Adalberto, $48^{\circ} 36^{\prime 28.7 "}$ S, 7453'55.7" W, sloping wall, some overhangs, high diversity of sponges, lots of Alcyonium, depth 30 m, coll. GF, 12 March 2006; ZSM 20061191, four colonies, Chile, Canal Pitt Chico, 5050'07.1" S, 7408'20.9" W, very mixed, steep walls, strong current, lots of hydrocorals and crabs, coll. VH \& GF, depth 22 m; 7 March 2006; RMNH Coel. 34939, one colony, Chile, Paso del Abismo, 49³4'38.7" S, 74²6'49.3" W, steep/overhanging wall, high diversity, depth 22 m, coll. VH \& GF, 10 March 2006; RMNH Coel. 34940, one colony and one microscope slide, Chile, Angostura Inglesias, 48 59'17.6" S, 74² $25^{\prime} 08.2^{\prime \prime} \mathrm{W}$, depth $26 \mathrm{~m}$, coll. VH \& GF, 11 March 2006; MZUC-UCCC 32680, one colony, Chile, Canal Adalberto, 48³6'28.7" S, 7453'55.7" W, depth 20-30 m, on gorgonian, sloping wall, some overhangs, high diversity of sponges, lots of Alcyonium, coll. PW \& LA, 12 March 2006; RMNH Coel. 34941, five colonies on a gorgonian branch, Chile, Canal Adalberto, 48 36'28.7" S, 7453'55.7" W, sloping wall, some overhangs, high diversity of sponges, lots of Alcyonium, depth $30 \mathrm{~m}$, coll. VH, 12 March 2006; MZUC-UCCC 32681, one colony, on dead gorgonian, Chile, Seno Waldemar, $48^{\circ} 23^{\prime} 48.5^{\prime \prime} \mathrm{S}, 74^{\circ} 43^{\prime} 48.8^{\prime \prime} \mathrm{W}$, slope/wall, some terraces, patches of high diversity, depth $25 \mathrm{~m}$, coll. GF, 15 March 2006; ZSM 20061192, two colonies, Chile, Grupo Dacres, 51³6'20.8" S, 7355'33.8" W, large steps with slight overhangs, high biodiversity, strong current convection, depth $11 \mathrm{~m}$, coll. VH \& GF, 7 March 2006; ZSM 20061193, one colony, Chile, Canal Castillo, 4844'11.4" S, 75²4'53.1" W, terraced wall, with high diversity, lots of Alcyonium and sponges, depth $23 \mathrm{~m}$, coll. VH, 12 March 2006. MZUC-UCCC 8156, three colonies, Isla Inocentes, 50³3' S, 7453' W, coll. H. Moyano, 9 October 1972.

Description of RMNH Coel. 34937. Colony consisting of a single, flattened, rounded lobe, $3.5 \mathrm{~cm}$ high, $3 \mathrm{~cm}$ wide, and $1.5 \mathrm{~cm}$ thick (Fig. 1e).

Polyps distributed over the whole surface of the colony, almost reaching the base. Calyces are dome shaped and all polyps are retracted.

Anthocodiae have a collaret composed of 5-6 rows of spindles (Fig. 3c); these spindles are up to $0.40 \mathrm{~mm}$ long, with simple tubercles (Fig. 6a). Points have spindles similar to those of the collaret, with clubs present distally, up to $0.25 \mathrm{~mm}$ long (Fig. 6b). In the tentacles spiny rods are found, up to $0.20 \mathrm{~mm}$ long (Fig. 6c).

The surface layer of the top of the colony has clubs, up to $0.20 \mathrm{~mm}$ long, with spiny heads (Fig. 6d); the interior has spindles with rather complex tubercles, up to $0.30 \mathrm{~mm}$ long (Fig. 6e).

The surface layer and interior of the base of the colony have sclerites similar to those of the top of the colony (Fig. 6f-g), but they are slightly shorter.

Colour. The orange colour of the live colony is still preserved; tentacle rods are colourless, other sclerites yellow. 


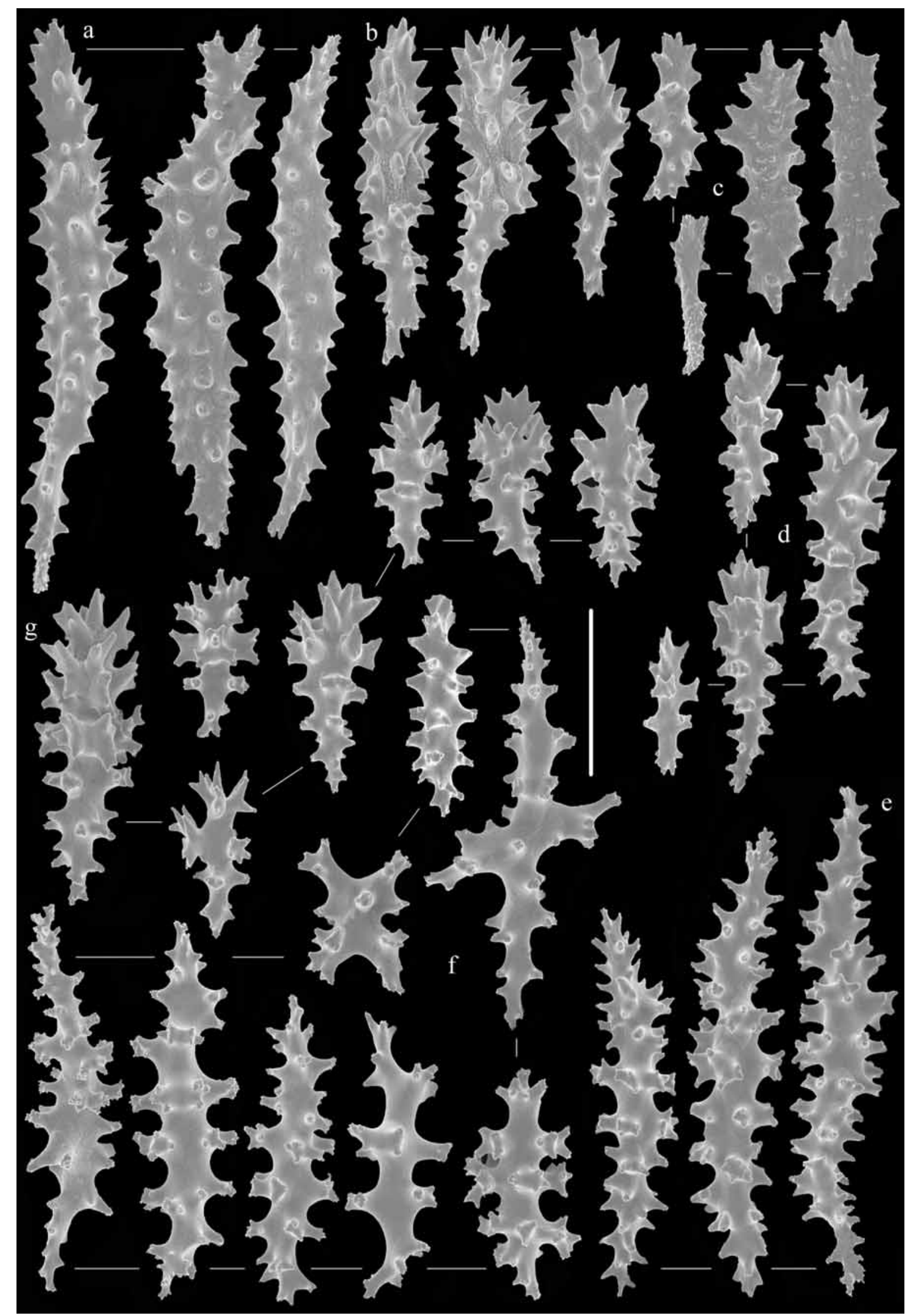

FIGURE 6. Alcyonium haddoni Wright \& Studer, RMNH Coel. 34937; a, collaret spindles; b, point clubs; c, tentacular rods; d, clubs of surface layer of top of colony; e, spindles of interior of top of colony; $f$, spindles of interior of base of colony; g, clubs of surface layer of base of colony. Scale $0.10 \mathrm{~mm}$. 


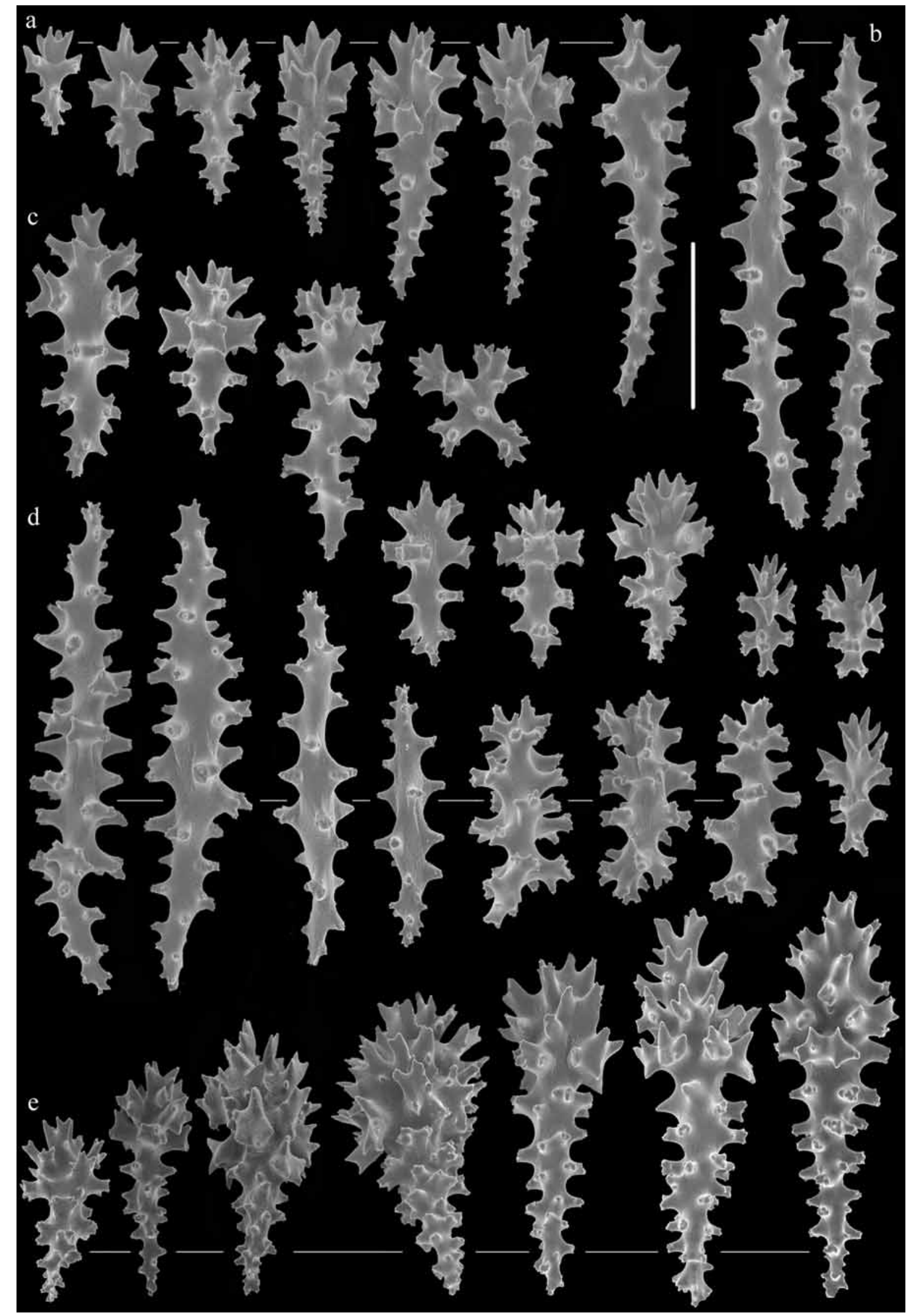

FIGURE 7. Alcyonium haddoni Wright \& Studer; a-d, RMNH Coel. 34940; e, MZUC-UCCC 8156; a, clubs of surface layer of top of colony; $b$, spindles of interior of top of colony; c, clubs of surface layer of base of colony; $d$, spindles of interior of base of colony; e, clubs of surface layer of top of colony. Scale $0.10 \mathrm{~mm}$. 
Habitat, distribution and abundance. This species is the most abundant of all Alcyonium species so far recorded in Chile. Specimens inhabit rocky and biogenic substrata (dead gorgonians, chitons) starting in $6 \mathrm{~m}$

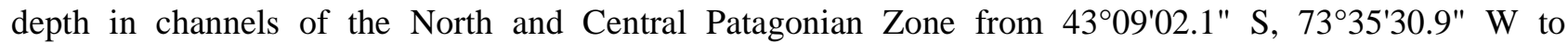
$51^{\circ} 36^{\prime} 20.8^{\prime \prime} \mathrm{S}, 73^{\circ} 55^{\prime} 33.8^{\prime \prime} \mathrm{W}$. The typical colonies are round to slightly elongated with a distinct domeshaped extremity and consist of a single lobe. On rare occasion, however, colonies are longer and/or slightly to strongly lobed with each lobe having a dome-shaped extremity (see variability). In several colonies, conspicuous pink eggs/larvae were visible through the transparent body wall of some polyps. On one colony (Fig. 3c) the amphipod Metepimeria acanthurus was observed.

Variability. RMNH Coel. 34938 is similar to RMNH Coel. 34937, but larger, with cream to orange color, and with many polyps expanded (Fig. 1f). Therefore, this specimen was used to make the drawing of the polyp armature (Fig. 3c). In this specimen the polyps are up to $1.20 \mathrm{~mm}$ wide and $1 \mathrm{~mm}$ high.

All recently collected material examined except two seem to consist of a single lobe. One of the colonies of ZSM 20061191 has some irregular outgrowths, probably re-growth after damage instead of real lobes. RMNH Coel. 34940 seems to be a digitate colony (Fig. 2c), but could be the result of several digitiform colonies grown together to form one large digitate colony. It surely is an exceptional growth form for this species and therefore SEM images of its sclerites (Fig. 7a-d) and a lateral view of its polyp armature (Fig. 3b) are presented. Specimen RMNH Coel. 34940 has somewhat larger anthocodial sclerites, up to $0.50 \mathrm{~mm}$ long, and the distal ones are less club-like. Furthermore its internal spindles are less tuberculate. We consider these differences intraspecific variation and despite its aberrant growth form to belong to A. haddoni.

The ZSM 20061190 colonies have a white base and polyps, with all anthocodial and base sclerites colourless.

Remarks. Alcyonium haddoni was described by Wright \& Studer (1889), found $315 \mathrm{~m}$ deep in the Messier Channel, Chile. In their publication the description of the colony shape was rather misleading (see remarks of A. roseum). Therefore, here two syntypes of A. haddoni (BMNH 89.5.27.125) are shown in Fig. 1d. Also the sclerites of this species were depicted rather schematic (pl. 42 fig. 6).

Verseveldt (1967) re-examined the syntype material of $A$. haddoni in order to identify material collected east from Rio de la Plata, Argentine. He noted some significant sclerite differences between his material and the syntypes but nevertheless decided the Rio de la Plata material belonged to A. haddoni. Two microscope slides of the top of the colony of a syntype, made by Verseveldt, are stored in the RMNH, and were re-examined by us. They showed much wider clubs in the top of the colony (up to $0.10 \mathrm{~mm}$ wide heads) than those in the recently collected material. Only after examining the MZUC-UCCC 8156 material did it become obvious that this difference probably represents intraspecific variation as MZUC-UCCC 8156 shows clubs (Fig. 7e) intermediate between the syntype and the recently collected material.

We have our doubts about the identification of Verseveldt (1967), the colonies he depicted are digitate and the clubs are even less developed than in our material.

It is very unlikely Pérez \& Zamponi (2004) had A. haddoni as their colony was clearly lobate.

Alcyonium paucilobulatum Casas et al., 1997, from the Scotia Arc, can have a similar looking colony shape. However, this species has mostly capstans and spherical sclerites in the surface layer of the coenenchyme. A. patagonicum (May, 1899), from the Patagonian shelf, also resembles the present species, but has a more finger-shaped colony form, and has wider interior spindles with coarser warts (see Verseveldt \& Ofwegen, 1992). Moreover, colonies of these two species are white to cream while A. haddoni has orange colonies.

\section{Alcyonium jorgei n. sp.}

(Figs. 1g, 2d-e, 3d, 8)

Holotype and one microscope slide: RMNH Coel. 34942, Chile, Puyuhuapi, 44²3'34.5" S, 72³4'54.9" W, depth 30 m, coll. VH \& GF, 10 January 2000. 


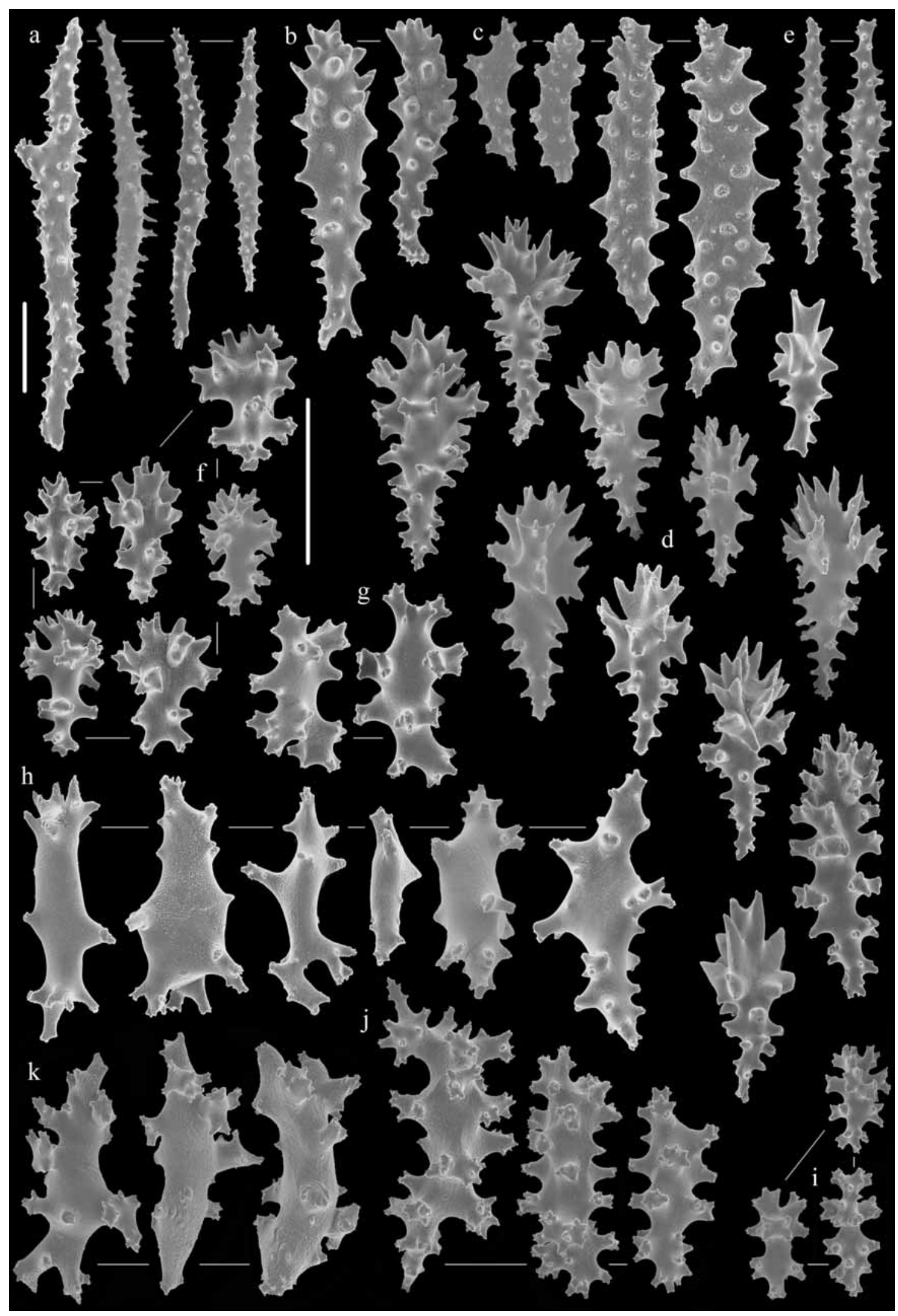

FIGURE 8. Alcyonium jorgei $\mathrm{n}$. sp.; a-h, holotype RMNH Coel. 34942; i-k, RMNH Coel. 34944; a, collaret spindles; b, point clubs; c, tentacular rods; d, clubs of surface layer of top of colony; e, spindles of interior of top of colony; f, clubs of surface layer of base of colony; g, capstans of surface of base of colony; h, spindles and rods of interior of base of colony; i, clubs of surface layer of base of colony; $j$, spindles of interior of base of colony; $k$, rods of interior of base of colony. Scales $0.10 \mathrm{~mm}$, that at a applies also to e, that at $\mathrm{f}$ to all others. 
Paratypes: MZUC-UCCC 32682, two colonies, Chile, Puerto Cisnes, 4443'29.1" S, 7241'24.2" W, depth 15-25 m, coll. VH \& GF, 4 January 2000; RMNH Coel. 34943, two microscope slides, same data; ZSM 20061194, two colonies, Chile, Puyuhuapi, 44²3'34.5" S, 72³4'54.9" W, coll. VH \& GF, 27 February 1998; RMNH Coel. 34945, two microscope slides, same data.

Other material: RMNH Coel. 34944, one colony and two microscope slides, Chile, Canal Ofhidro, 48 $09^{\prime} 52.1^{\prime \prime} \mathrm{S}, 74^{\circ} 23^{\prime} 48.4^{\prime \prime} \mathrm{W}$, steep wall, low diversity, few overhangs, depth $25 \mathrm{~m}$, coll. VH, 16 March 2006.

Description. Holotype $3.5 \mathrm{~cm}$ high and $2.5 \mathrm{~cm}$ wide, consisting of a very short stalk only a few $\mathrm{mm}$ long, and a main stem with short slender lobes of about $1 \mathrm{~cm}$ length (Fig. 1g).

Polyps are distributed all over the stem and lobes, but are most abundant at the end of the lobes. Calyces are dome shaped and all polyps are partly retracted with tentacles withdrawn. The polyps are up to about 1.00 mm wide and high.

Anthocodiae have a collaret composed of 5 to 6 rows of spindles (Fig. 3d). The collaret spindles are up to $0.50 \mathrm{~mm}$ long, with simple tubercles (Fig. 8a). Points have spindles similar to those of the collaret; with clubs present distally, up to $0.20 \mathrm{~mm}$ long (Fig. 8b). In the tentacles spiny rods are found, up to $0.25 \mathrm{~mm}$ long (Fig. $8 \mathrm{c})$.

The surface layer of the lobes has clubs, up to $0.20 \mathrm{~mm}$ long, with spiny heads (Fig. 8d); the interior has spindles with simple tubercles, up to $0.35 \mathrm{~mm}$ long (Fig. 8e).

The surface layer of the stalk has short clubs, up to $0.10 \mathrm{~mm}$ long (Fig. 8f), and capstans, which are slightly longer than the clubs (Fig. 8g); the interior of the stalk contains spindles and rods, up to $0.20 \mathrm{~mm}$ long (Fig. 8h).

Colour. Alive (Fig. 2d-e) and preserved the colonies are yellowish to orange; smallest tentacular sclerites are colourless, all other sclerites yellow.

Etymology. The species is named after the ex-rector of the Pontificia Universidad Catolica de Valparaiso, Chile, Jorge Gonzalez Foster.

Habitat, distribution and abundance. The species was regularly found in the continental fjords of the Northern Patagonian Zone and possibly (see remarks) once in the fjords of the Central Patagonian Zone. $\left(44^{\circ} 23^{\prime} 34.5^{\prime \prime} \mathrm{S}, 72^{\circ} 34^{\prime} 54.9^{\prime \prime} \mathrm{W}\right.$ (probably $41^{\circ} 35^{\prime} \mathrm{S}$ to $44^{\circ} 50^{\prime} \mathrm{S}$, photographs only) to possibly $48^{\circ} 09^{\prime} 52.1^{\prime \prime} \mathrm{S}$, $74^{\circ} 23^{\prime} 48.4^{\prime \prime} \mathrm{W}$ ), in depths below 15-20 m. It inhabits moderately steep to vertical rocky substratum. In contrast to A. glaciophilum, which also is found in the inner fjords, it appears only at sites with low to moderate sedimentation.

Variability. One colony of MZUC-UCCC 32682 has two lobes, the other is unbranched, and only $1 \mathrm{~cm}$ long; RMNH Coel. 34944 is also unbranched, but $2 \mathrm{~cm}$ long. The two colonies of ZSM 20061194 are both branched, one with only one side lobe.

Both ZSM 20061194 colonies are whitish; their sclerites are dull yellow and many are broken.

RMNH Coel. 34944 is yellowish orange, with all anthocodial sclerites colourless, and the base with a mixture of colourless and yellow sclerites.

Remarks. Because RMNH Coel. 34944 has a rather long stalk, compared with the other specimens, SEM images of its sclerites are presented as well (Fig. 8i-k). It shows capstans and clubs similar to those of the other material, but the sclerites of the interior of the base (Fig. 8j-k) are more irregularly shaped. As only one specimen was available with these characters we tentatively included it in this species.

Alcyonium jorgei n. sp. resembles A. yepayek n. sp.; both species have digitate colonies, and both have similar rods in the interior of the colony. A. jorgei differs in having more slender lobes, and clubs with more spiny heads, and mostly without central wart. 
Alcyonium roseum $\mathbf{n}$. sp.

(Figs. 1h, 2f-g, 3e, 9)

Holotype and three microscope slides: RMNH Coel. 34946, Chile, Bernardo, Fjord Isla van der Meulen SE, 48 17'13.0" S, 74²0'10." W, depth 25 m, coll. VH \& GF, 28 March 2005.

Paratypes: MZUC-UCCC 32683, Chile, Canal Messier, Puerto Eden/Isla Pedro, 48 58'29" S, 74²5'16.9" W, boulders of different sizes, moderate slope, depth 26 m, coll. VH \& GF, 1 April 2005; ZSM 20061195, Chile, Paso del Abismo, 49³4'38.7" S, 74²6'49.3" W, steep/overhanging wall, high diversity, depth $25 \mathrm{~m}$, coll. VH \& GF, 10 March 2006; ZSM 20061196, Chile, Seno Waldemar, 48²3'48.5" S, 7443'48.8" W, slope/ wall, some terraces, patches of high diversity, depth 25 m, coll. VH, 15 March 2006; RMNH Coel. 34947, Chile, Grupo Dacres, 51 $36^{\prime} 20.8^{\prime \prime}$ S, $73^{\circ} 55^{\prime} 33.8^{\prime \prime} \mathrm{W}$, large steps with slight overhangs, high biodiversity, strong current convection, depth 15 m, coll. VH \& GF, 7 March 2006.

Description. The holotype is membranous, about $20 \mathrm{~cm}$ long and about $1 \mathrm{~mm}$ thick, completely encrusting the axis of a gorgonian (Figs. 1h, 2f). At irregular intervals small lobes are present, these are up to about 1 $\mathrm{cm}$ high and wide.

Polyps are unevenly distributed over the colony; they are concentrated on the lobes, where they stand in close proximity. Calyces are dome shaped and most polyps are retracted, the few expanded polyps are up to 2 $\mathrm{mm}$ high and $1.5 \mathrm{~mm}$ wide; all polyps have the tentacles withdrawn.

Anthocodiae have a collaret composed of 5-6 irregularly arranged rows of spindles; the points with many spindles (Fig. 3e). The anthocodial spindles are up to $0.55 \mathrm{~mm}$ long, with simple tubercles (Fig. 9a-b). At the tentacle bases slender clubs are present, up to $0.30 \mathrm{~mm}$ long (Fig. 9c). In the tentacles spiny rods are found, up to $0.20 \mathrm{~mm}$ long (Fig. 9d).

The surface layer of the lobes has clubs, up to about $0.25 \mathrm{~mm}$ long, with spiny heads (Fig. 9e). The interior of the lobes has tuberculated spindles, up to $0.30 \mathrm{~mm}$ long (Fig. 9f).

The surface layer of the membrane has capstans and clubs (Fig. 9g). The capstans are up to about 0.10 $\mathrm{mm}$ long, most of the clubs are slightly longer, some reaching $0.25 \mathrm{~mm}$ in length. The interior of the membrane contains tuberculated spindles (Fig. 9h), up to $0.30 \mathrm{~mm}$ long; similarly shaped to those of the lobes.

Colour. Alive the colony was pink (Fig. 2f), preserved it is white, and all sclerites are colourless.

Etymology. The species name is the Latin roseum, rose, referring to the colony colour.

Habitat, distribution and abundance. The species was regularly found on biogenic substrata (e.g. dead gorgonians, polychaete tubes) which were found on moderately steep or vertical rocky substratum below $15 \mathrm{~m}$ depth in the channels of the Central Patagonian Zone (see Pickard, 1973) between 48 $177^{\prime} 30^{\prime \prime} \mathrm{S}, 74^{\circ} 20^{\prime} 10^{\prime \prime} \mathrm{W}$ and $51^{\circ} 36^{\prime} 20.8^{\prime \prime} \mathrm{S}, 73^{\circ} 55^{\prime} 33.8^{\prime \prime} \mathrm{W}$ in the Chilean fjord region. At these sites currents were moderate to strong and sedimentation relatively low. The colonies can cover entire dead gorgonians or just a part of them.

Variability. The paratypes are similar to the holotype, also encrusting gorgonians, but forming smaller colonies (Fig. 2g).

Remarks. Alcyonium antarcticum Wright \& Studer, 1889, from Antarctic and Sub Antarctic waters, and A. haddoni Wright \& Studer, 1889, from the Messier Channel, Chile, have been described as having membranous colony forms. A. antarcticum indeed can be membranous (see Verseveldt \& Ofwegen, 1992), but Wright \& Studer described their A. haddoni as "In this species the colony forms very variously shaped and sized masses, which grow over the dead stems of a Muriceid", suggesting it has a membranous colony form. However, none of the three specimens mentioned in their publication was depicted. Here we show two of these syntype specimens of A. haddoni, BMNH 89.5.27.125 (Fig. 1d), which clearly demonstrate it is not an encrusting species.

A. antarcticum differs from the present species in having less tuberculate capstans in the surface and lacking the characteristic clubs at the tentacle bases reported for the present material.

Above we described encrusting specimens of A. grandis Casas et al. That species differs from Alcyonium roseum $\mathrm{n}$. sp. in totally lacking clubs. 


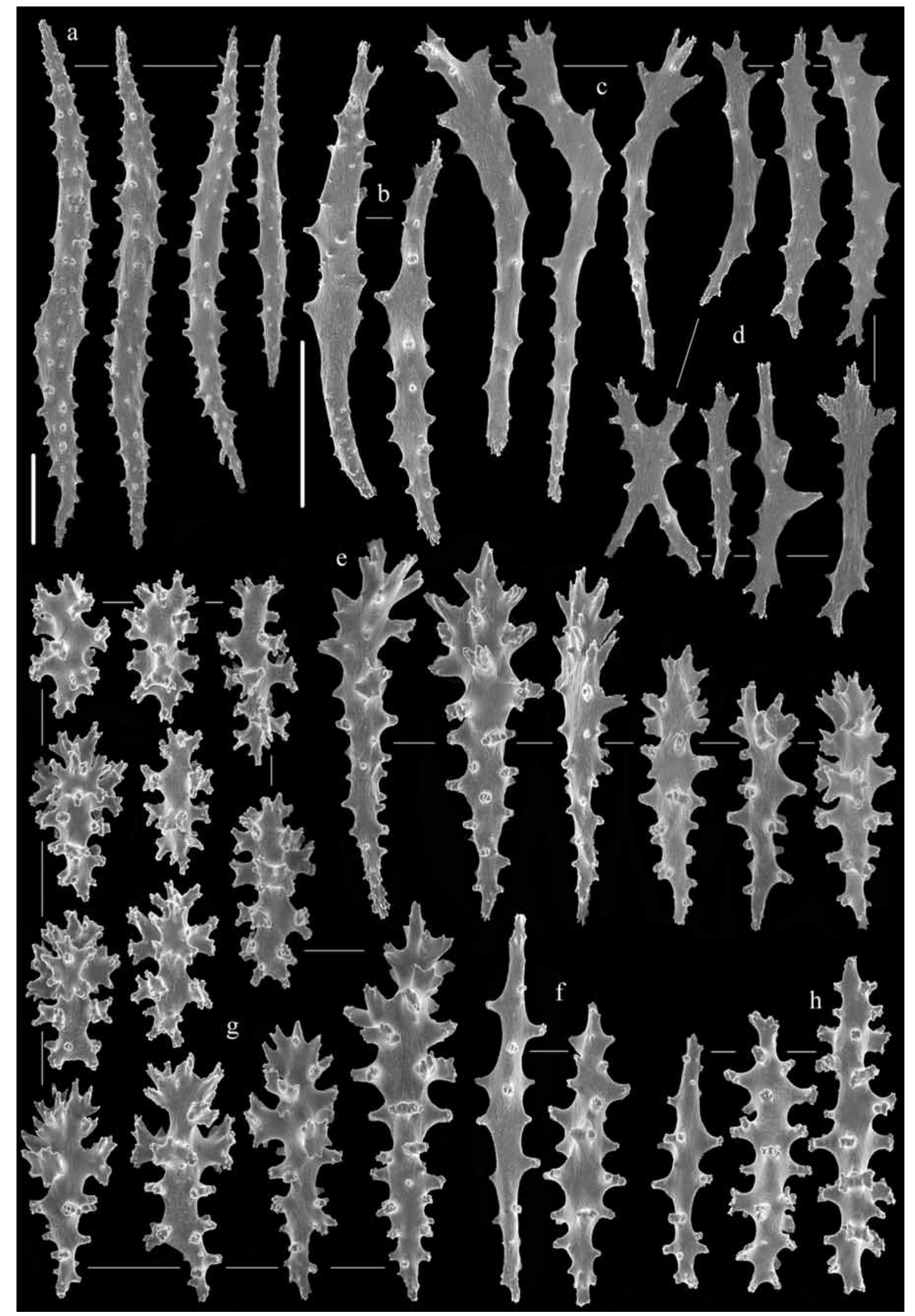

FIGURE 9. Alcyonium roseum n. sp., holotype RMNH Coel. 34946; a-b, anthocodial spindles; c, clubs of tentacle bases; d, tentacular rods; e, clubs of surface layer of top of lobe; $f$, spindles of interior of top of lobe; g, capstans and clubs of membrane; $h$, spindles of membrane. Scale $0.10 \mathrm{~mm}$, that at a only applies to $\mathrm{a}$, that at $\mathrm{b}$ to all others. 


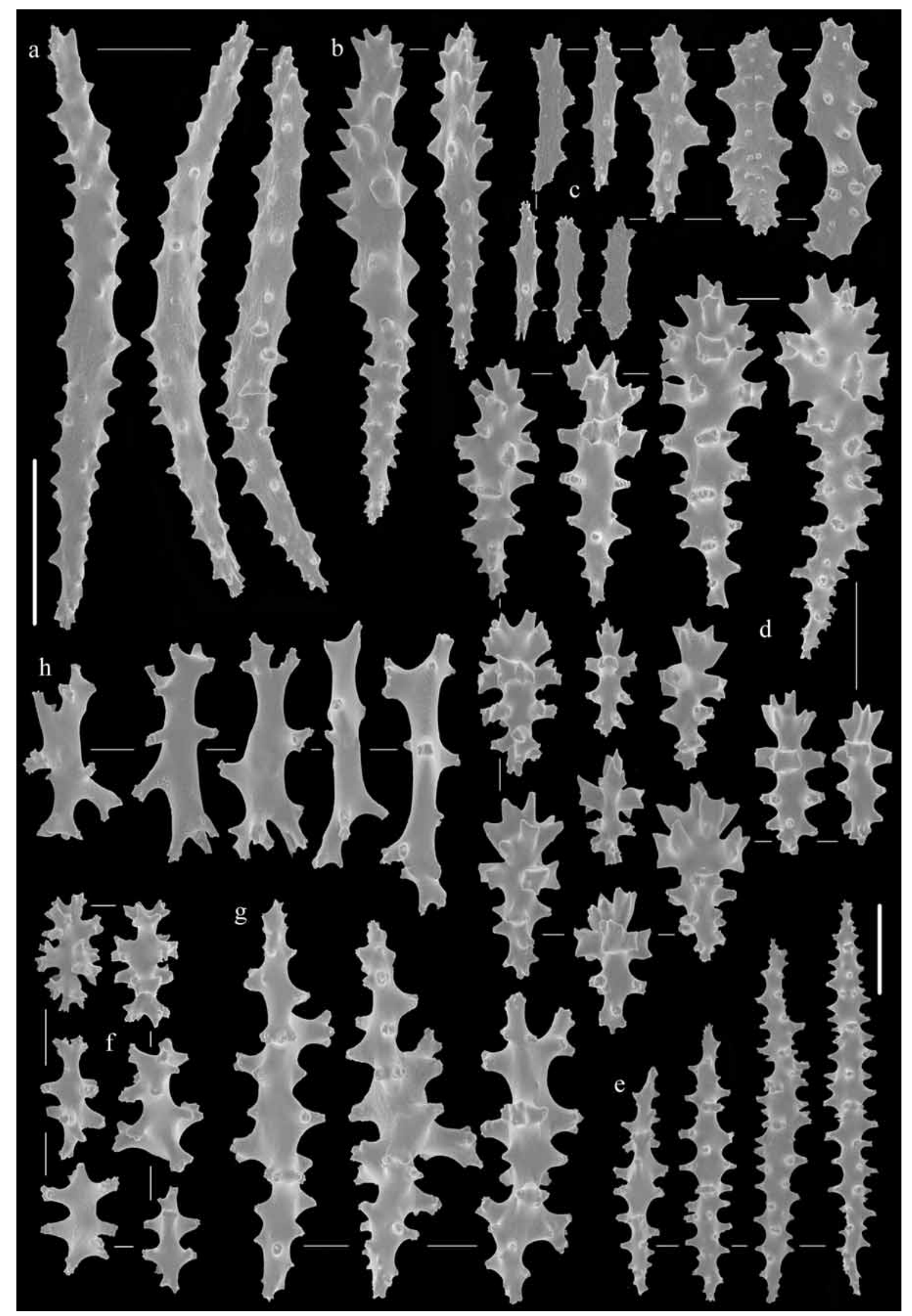

FIGURE 10. Alcyonium yepayek n. sp., holotype RMNH Coel. 34948; a, collaret spindles; b, point clubs; c, tentacular rods; $d$, clubs of surface layer of top of colony; e, spindles of interior of top of colony; $f$, capstans of surface layer of base of colony; $g$, spindles of interior of base of colony; $h$, rods of interior of base of colony. Scales $0.10 \mathrm{~mm}$, that at e applies to e only, that at a to all others. 
Alcyonium yepayek n. sp.

(Figs. 1i, 2h, 10)

Holotype: RMNH Coel. 34948, Chile, Canal Pitt Chico, 5050'07.1" S, 7408'20.9" W, depth 17 m, very mixed, steep walls, strong current, lots of hydrocorals and crabs, coll. VH \& GF, 7 March 2006.

Paratypes: MZUC-UCCC 32684, one colony, Chile, Bernardo Area, Canal Caldcleugh N middle, 48 24'46.4" S, 74¹8'23.6" W, depth 9 m, coll. VH \& GF, 29 March 2005; RMNH Coel. 34949, two microscope slides, same data as MZUC-UCCC 32684; ZSM 20061197, one colony, Chile, Fjord Bernardo, Boca Bernardo S (Canal Farquhar), 48³4'40" S, 74²0'18" W, depth 13 m, coll. VH \& GF, 30 March 2005.

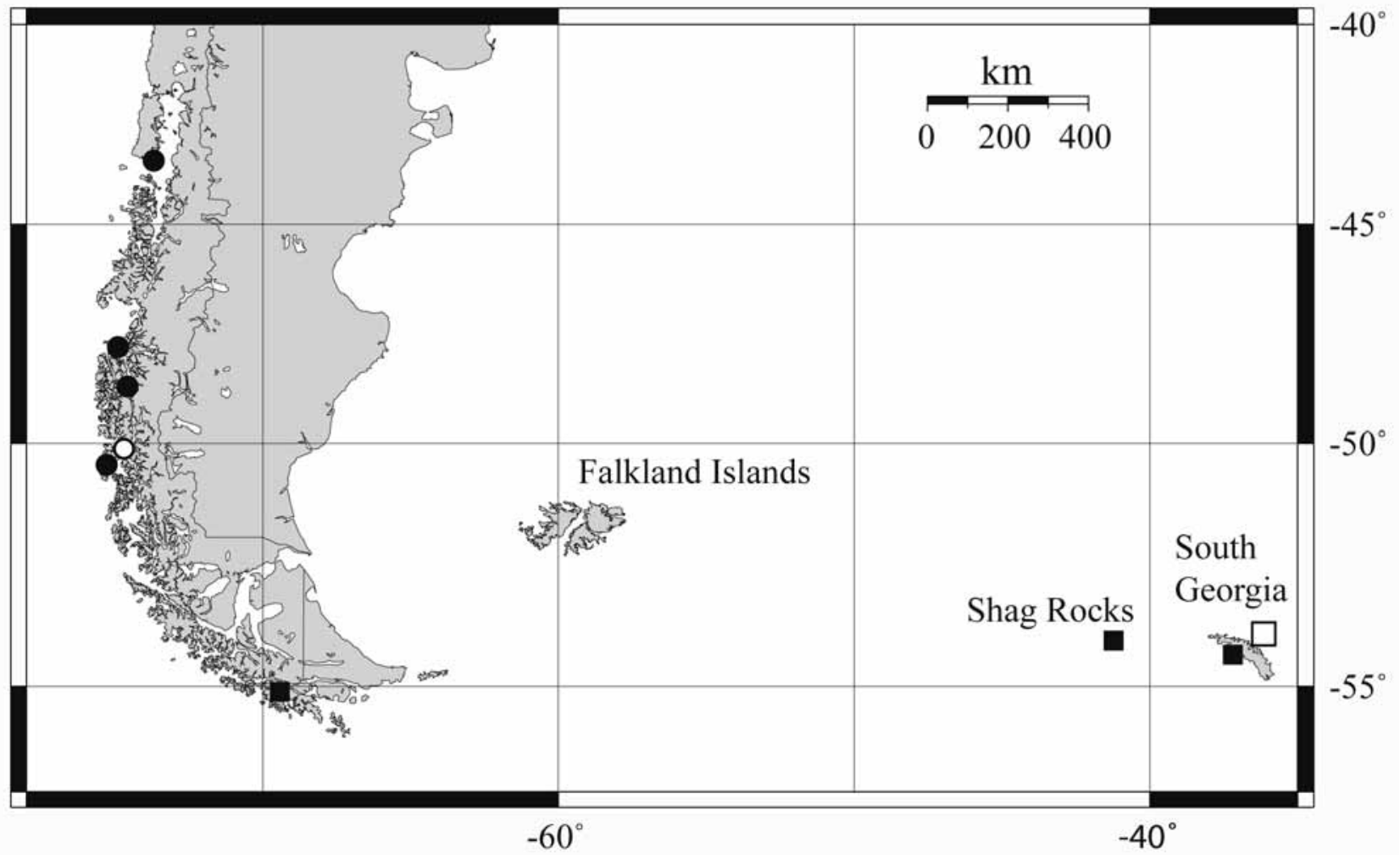

FIGURE 11. Distribution of Alcyonium grandis Casas et al., 1997 (empty square = type locality) and A. haddoni Wright \& Studer, 1889 (empty circle is type locality).

Description. The holotype consists of three lobes encircling a gorgonian branch (Fig. 1i). The largest lobe is one $\mathrm{cm}$ long and wide, the other two are smaller, a real stalk is lacking.

Because all polyps were retracted in the material studied the arrangement of anthocodial sclerites was not examined. The collaret spindles are up to $0.35 \mathrm{~mm}$ long, with simple tubercles (Fig. 10a). Points have spindles similar to those of the collaret, with clubs present distally, up to $0.15 \mathrm{~mm}$ long (Fig. 10b). In the tentacles spiny rods are found, up to $0.15 \mathrm{~mm}$ long (Fig. 10c).

The surface layer of the lobes has small clubs, mostly up to $0.15 \mathrm{~mm}$ long, a few up to $0.25 \mathrm{~mm}$ long, with leafy heads, and many of them with a central wart (Fig. 10d); the interior has spindles with simple tubercles, up to $0.40 \mathrm{~mm}$ long (Fig. 10e).

The surface layer of the base of the colony has tiny capstans (Fig. 10f), up to $0.10 \mathrm{~mm}$ long; the interior has spindles and rods, up to $0.25 \mathrm{~mm}$ long (Fig. 10g-h).

Colour. Alive (Fig. 2h) and preserved the colonies are orange. Most anthocodial and the smaller interior sclerites are colourless, all others yellow. 
Etymology. The species is named after the vessel of the CONAF (national park rangers) of the XIIth region, Yepayek, on which the sampling expeditions were carried out.

Habitat, distribution and abundance. The species was found between 9 and $17 \mathrm{~m}$ on rocky and biogenic substrata (mussels) of channels in the Central Patagonian Zone $\left(48^{\circ} 24^{\prime} 46.4^{\prime \prime} \mathrm{S}, 74^{\circ} 18^{\prime} 23.6^{\prime \prime} \mathrm{W}\right.$ to $\left.50^{\circ} 50^{\prime} 07.1^{\prime \prime} \mathrm{S}, 74^{\circ} 08^{\prime} 20.9^{\prime \prime} \mathrm{W}\right)$. Locally it was abundant.

Variability. Both MZUC-UCCC 32684 and ZSM 20061197 are a few $\mathrm{cm}$ high and about $1.5 \mathrm{~cm}$ wide, with digitiform colony shape, although some slight swellings, which could be the beginning of lobes, are visible. Contrary to the holotype both paratypes have clubs in the base of the colony; these are up to $0.10 \mathrm{~mm}$ long, and similar in shape to the clubs of the top of the colony.

Remarks. Alcyonium yepayek n. sp. resembles A. jorgei $\mathrm{n}$. sp. with regards to the internal rods, but differs in having wider lobes and most clubs having a central wart. It also resembles A. glaciophilum n. sp. but that species has much longer rods in the interior, which are also present in the top of the colony.

\section{Acknowledgments}

Mr. M. Slierings (NNM) is thanked for curatorial assistance. The sampling trips to the Central Patagonian Zone have been supported by the PADI Foundation, CONAF, Huinay Foundation, Témpano Project, and NAVIMAG. Many thanks to all of them. Also thanks to IMOPAC (Guarella) for their hospitality. This is publication $n^{\circ} 19$ of Huinay Scientific Field Station.

\section{References}

Casas, C., Ramil, F. \& Ofwegen, L.P. van (1997) Octocorallia (Cnidaria: Anthozoa) from the Scotia Arc, South Atlantic Ocean. I. The genus Alcyonium Linnaeus, 1758. Zoologische Mededelingen Leiden, 71 (26), 299-311.

Ehrenberg, C.G. (1831) Symbolae physicae, seu icones et descriptiones corporum naturalium novorum . . Pars Zoologica 4. Berlin.

Haeckel, E. (1866) Generelle Morphologie der Organismen. Berlin, pp. 1036.

May, W. (1889) Alcyonarien. In: Hamburger Magelhaensischen Sammelreise. Hamburg, L. Friederichsen \& Co, 1-22.

Lamouroux, J.V.F. (1812) Extrait d'un mémoire sur la classification des polypiers coralligènes non entierement pierreux. Nouveau Bulletin des Sciences par la Société Philomatique, Paris, 3 (63), 181-188.

Linnaeus, C. (1758) Systema naturae. Editio decima, reformata. 1: i-iv + 1-824. Holmiae.

Ofwegen, L.P. van, Häussermann, V. \& Försterra, G. (2006) A new genus of soft corals (Octocorallia: Alcyonacea: Clavulariidae) from Chile. Zootaxa, 1219, 47-57.

Pérez, C.D. \& Zamponi, M.O. (2004) New records of octocorals (Cnidaria, Anthozoa) from the south western Atlantic Ocean, with zoogeographic considerations. Zootaxa, 630, 1-12.

Pickard, G.L. (1973) Water structure in Chilean fjords. Oceanography of the South Pacific. R. Fraser. Wellington, New Zealand National Commission for UNESCO, 95-104.

Verseveldt, J. (1967) The Octocorallia Collected by R/V "Vema" in the Atlantic Ocean. American Museum Novitates, $2282,1-19$.

Verseveldt, J. \& Ofwegen, L.P. van (1992) New and redescribed species of Alcyonium Linnaeus, 1758 (Anthozoa: Alcyonacea). Zoologische Mededelingen Leiden, 66 (7), 155-181.

Wright, E.P. \& Studer, T. (1889) Report on the Alcyonaria collected by H.M.S. Challenger during the years 18731876. - Report on the Scientific Results on the Exploring. Voyage of H.M.S. Challenger Zoology 31, i-lxxvii + 1314. 